\title{
PREDATORY INSECT SPECIES ASSOCIATED WITH SOME ROSACEOUS PLANTS IN EDİRNE (TRAKYA UNIVERSITY ARBORETUM), TURKEY
}

\author{
Seda Emel TEK*, Zuhal OKYAR \\ Trakya University, Faculty of Science, Department of Biology, 22030, Edirne. \\ *Corresponding author: e-mail: sedaemeltek@gmail.com
}

Received (Alınış): 26 Sep 2016, Accepted (Kabul): 13 Nov 2017, Online First (Erken Görünüm): 24 Nov 2017, Published (Basım): 15 Dec 2017

\begin{abstract}
This study was performed to determine the predatory insects associated with Rosaceae species. Field surveys were carried out in March-June 2013 in Edirne province (Trakya University Arboretum) of European Turkey. Predatory insects were observed and collected in different stages of their life cycles, and larval-pupal samples were reared in laboratory conditions. As a result of this study, predatory insect species which are inhabitants of the Rosaceae species to provide their preys were recorded and 11 predatory insects belonging to 6 families (Chrysopidae, Coccinellidae, Formicidae, Geocoridae, Pentatomidae, Syrphidae) were determined on 5 Rosaceae species. The observations and short information about the recorded species were also presented.
\end{abstract}

Key words: Trophic interaction, biocontrol, Rosaceae, Turkish Thrace.

\section{Edirne Civarında (Trakya Üniversitesi Arboretumu) Bazı Rosaceae Bitkileri ile Birlikteliğe Sahip Predatör Böcek Türleri}

Özet: Rosaceae türleri ile etkileşime sahip predatör böcek türlerini belirlemek amaciyla, 2013 yılı Mart-Haziran periyodunda, Trakya Bölgesi sınırları içinde yer alan Edirne ilinde (Trakya Üniversitesi Arboretumu) arazi çalışması ve toplanan örneklerle ilgili olarak laboratuar çalışması yapılmıştır. Arazi çalışması sırasında predatör böcekler çeşitli yaşam evrelerinde gözlemlenmiş ve toplanmıştır. Toplanan örneklerden larva/pupa aşamasında olanlar laboratuar şartlarında yetiştirilmiştir. Çalışma sonucunda alanda bulunan Rosaceae türleri üzerinde konaklayan ve besinini sağlayan predatör böcekler tanımlanarak belirlenmiş ve 5 bitki türü üzerinde, 6 familyaya ait 11 predatör böcek türü (Chrysopidae, Coccinellidae, Formicidae, Geocoridae, Pentatomidae, Syrphidae) kaydedilmiştir. Tespit edilen türler hakkında yapılan gözlemler ve kısa literatür bilgileri de belirtilmiştir.

Anahtar kelimeler: Trofik etkileşim, biyokontrol, Rosaceae, Türkiye Trakyası.

\section{Introduction}

Most of the members of the Rosaceae family are crucial to human beings' way of life since the family includes trees, shrubs and herbaceous plants which are used for landscaping and timber making as well as other related species which are used for production of medicine and food (Flora of China 2004, Hummer and Janick 2009).

Predatory insects are among the natural enemies of several major economically depreciating pest species. Plants affect both insect herbivores and predators by their phenology, chemistry, morphology, and alternative food which they provide to these insects. Plants provide food and shelter for herbivorous insects but on the other hand they can defense themselves directly or indirectly against herbivory by using their traits. One example can be given in terms of plant allelochemicals. A type of allelochemical called "pine tree terpenoids" can behave as allomones, kairomones and synomones against the organisms around it. This substance released by a plant species can deter herbivores by acting as an allomone, attract bark beetles by acting as a kairomone and attract bark beetle predators by acting as a synomone. Hence, pine tree terpenoids produced by the host tree is beneficial to both the plant and the predator. Another typical example is the aphidplant-predator relationship. Studying the tritrophic associations between an aphid, its plant food and its predator can show the affects each offers to the others. These tritrophic studies reveal a lot about the overall beneficial effects that plants have to offer and the outcomes of these studies contribute to the importance of plant protection (Kilınçer 1983, Barbosa and Letourneau 1988, Schmitz et al. 2000, Vanhaelen et al. 2002, Schoonhoven et al. 2005). In the special case of Rosaceae family, it is also important to reveal the predatory insects and their associations or interactions with herbivorous insects and plant species they feed on. Thus, any kind of knowledge about plant-predatory insects is important both for agriculture and biodiversity. Although there are a 
number of studies reporting biological observations on predatory insect species found on several Rosaceae species like apple, peach, cherry and other fruit trees in different regions of Turkey (Kılıç and Aykaç 1989, Çam 1993, Çınar et al. 2004, Başar and Yaşar 2011, Demirözer and Karaca 2014) no study about the predators on rosaceous plants was performed so far in our present study area. The aim of this study is to contribute to the knowledge of predatory species associated with some rosaceous plants in Turkey.

\section{Materials and Methods}

Predatory insects were investigated following the emergence of herbivores in parallel with the blooming season of Rosaceae plants (in March) in Trakya University Balkan Arboretum in Edirne province of European Turkey (Fig. 1). The study area (200 hectares) was an uncultivated field without pesticide treatment. Field surveys were carried out from March to June 2013 but the total time period of the study covered 1 year to include the steps in laboratory. Predatory insects were collected individually in the field at their larval, pupal and adult stages. The collections were performed on Crataegus monogyna Jacquin, Prunus $\mathrm{x}$ domestica Linnaeus, $P$. spinosa Linnaeus, Pyrus communis Linnaeus and Rubus sanctus Schreber. The field studies were performed from March to June as 2 days/week due to the seasonal conditions of the region and the biological features of the species. Insect diversity showed a parallel increase with the plant development reaching its peak within this time period. In the field, the flowers, leaves, and stems of the plants were observed carefully and individual insects or their nests seen on each plant were collected gently. Larval and adult stages of insects were captured (after their observation) directly from the plant or from a cloth beneath the plant after shaking it using a forceps or by hand-picking. Pupal stages and nests were collected by removing the plant leaves. Larval and pupal samples were placed in $10 \times 10 \mathrm{~cm}$ gauze-covered plastic rearing boxes and were reared in laboratory conditions (temperature $27^{\circ} \mathrm{C}$; relative humidity $52 \%$ ) by feeding the larvae with aphids. Adult samples were directly put into small jars containing $70 \%$ ethanol and then brought to laboratory. All rearing boxes and ethanol filled jars were labeled including number of the sample, related plant species, study area, and date of the collection. All adult insects were appropriately prepared and then identified by experts.

\section{Results}

A total of 11 predatory insects from 6 families were sampled either as larval, pupal or adult stages on 5 Rosaceae species (Table 1).

Coccinella bipunctata Linnaeus, C. septempunctata Linnaeus, Exochomus quadripustulatus Linnaeus, Harmonia axyridis Pallas (Col.: Coccinellidae) and Eupeodes corollae (Fabricius) (Dip.: Syrphidae) were collected from their associated plants (Table 1) only in their larval stages. The larvae were observed around aphid colonies on the sampled plants and were reared into adults in laboratory by feeding them with aphids. Episyrphus balteatus (De Geer) was collected both in larval and pupal stages and was reared into adult in laboratory. Cannibalism was observed between the last instar larvae of $C$. septempunctata and those of $H$. axyridis.

Chrysopa viridana Schneider and C. pallens Rambur (Neur.: Chrysopidae) were collected in their pupal stages from their associated plants (Table 1) and developed to adults in laboratory rearings. Pupae of $C$. pallens were determined in their nests built on hawthorn and blackthorn. The nests looked like a tent made from old leaves, with only a small pupa in a nest.

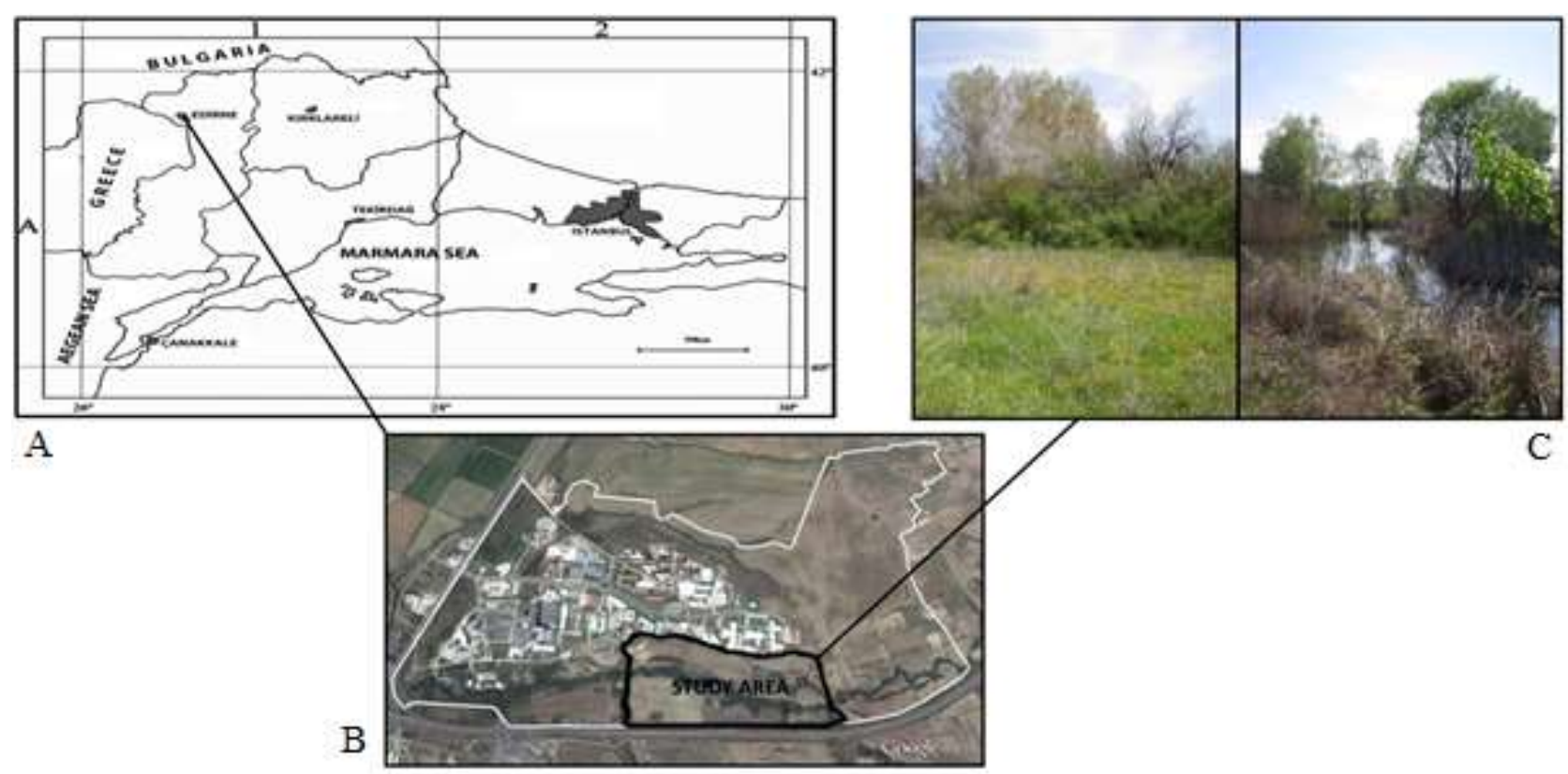

Fig. 1. (A) Map of European Turkey. (B) The study area, Trakya University Balkan Campus (white-lined area) and the arboretum (black-lined area) (Google Earth 2015). (C) The general view of the study area. 
Table 1. Predatory insects and their associated Rosaceae plants recorded during the study. ${ }^{(1)}$ : individuals collected from the field in larval stage; ${ }^{(2)}$ : collected in pupal stage; ${ }^{(3)}$ : collected in adult stage; ${ }^{(4)}$ : non-herbivorous at all life stages.

\begin{tabular}{|c|c|}
\hline Rosaceae Plant & Predatory Insect \\
\hline Crataegus monogyna Jacquin (hawthorn) & Chrysopa pallens Rambur $^{(2)}$ (Neuroptera: Chrysopidae) \\
\hline Prunus x domestica Linnaeus (plum) & $\begin{array}{l}\text { Coccinella bipunctata } \text { Linnaeus }^{(1)} \text { (Coleoptera: Coccinellidae) } \\
\text { Coccinella septempunctata Linnaeus }{ }^{(1)} \text { (Coleoptera: Coccinellidae) } \\
\text { Harmonia axyridis } \text { Pallas }{ }^{(1)}(\text { Coleoptera: Coccinellidae) } \\
\text { Episyrphus balteatus }\left(\text { De Geer) }{ }^{(1)} \text {, (2) }(\text { Diptera: Syrphidae) }\right. \\
\text { Eupeodes corollae }\left(\text { Fabricius) }{ }^{(1)} \text { (Diptera: Syrphidae) }\right. \\
\text { Chrysopa viridana Schneider }{ }^{(2)} \text { (Neuroptera: Chrysopidae) }\end{array}$ \\
\hline Prunus spinosa Linnaeus (blackthorn) & $\begin{array}{l}\text { Coccinella septempunctata } \text { Linnaeus }^{(1)} \text { (Coleoptera: Coccinellidae) } \\
\text { Geocoris erythrocephalus }\left(\text { Lepeletier \& Serville) }{ }^{(3)} \text { (Hemiptera: Geocoridae) }\right. \\
\text { Perillus bioculatus }\left(\text { Fabricius) }{ }^{(3)} \text { (Hemiptera: Pentatomidae) }\right. \\
\text { Chrysopa pallens } \text { Rambur }{ }^{(2)} \text { (Neuroptera: Chrysopidae) }\end{array}$ \\
\hline Pyrus communis Linnaeus (pear) & Exochomus quadripustulatus Linnaeus ${ }^{(1)}$ (Coleoptera: Coccinellidae) \\
\hline Rubus sanctus Schreber (wild blackberry) & $\begin{array}{l}\text { Coccinella septempunctata Linnaeus }{ }^{(1)} \text { (Coleoptera: Coccinellidae) } \\
\text { Perillus bioculatus } \text { (Fabricius) }^{(3)} \text { (Hemiptera: Pentatomidae) } \\
\text { Crematogaster ionia } \text { Forel }^{(3),(4)} \text { (Hymenoptera: Formicidae) }\end{array}$ \\
\hline
\end{tabular}

Geocoris erythrocephalus (Lepeletier \& Serville) (Hem.: Geocoridae) was collected as adults from blackthorn by shaking the plant or observed between the leaves.

Perillus bioculatus (Fabricius) (Hem.: Pentatomidae) were observed gregariously in their first or second nymphal stages on blackthorn and wild blackberry stems.

Crematogaster ionia Forel (Hym.: Formicidae) adults (workers) were observed between wild blackberry bush leaves. 5-6 individual ants were continuously moving in and out of a nest looked like a leafrollers' nest, as if they were feeding and storing; it probably was a Tortricidae pupa.

\section{Discussion}

Chrysopa viridana and C. pallens (Chrysopidae) are generalist predators but they also feed on pollen rich in proteins, carbohydrates, fats, and vitamins (Bozsik 1992, Lundgren 2009). Chrysophid species are important biological control agents of aphids, mites and coccids. $C$. pallens, one of most well-studied chrysophid, is used in biocontrol of aphids, lepidoptera larvae, mites, and thrips which are major economically depreciating arthropods (Lundgren 2009, Pappas et al. 2011). The adult or larval individuals of $C$. viridana and $C$. pallens were documented on rosaceous plants in previous studies. Aldini (2012) recorded adults of these chrysopid species on plum trees and Paulan et al. (2001) and Bozsik (2006) documented them on Crataegus monogyna and Prunus spinosa. Tritrophic view includes that plant volatiles have an impact on herbivores and on predators and parasitoids as their natural enemies. Herbivore-induced plant chemicals affect natural enemies and attract them to the plants to find the herbivores (McEwen et al. 2001). For instance, it was reported that the silver vine Actinidia polygama Siebold \& Zuccarini attracted Chrysopa pallens by releasing two dihydronepetalactols (Hyeon et al. 1968, van Emden and Harrington 2007). Boo et al. (1998) proved that $C$. pallens adults responded to aphid-induced sex pheromones as kairomones. In the present study, $C$. pallens and $C$. viridana were found on blackthorn, hawthorn, and plum in their pupal stages. Therefore, the possible effects of rosaceous plant allelochemicals on these chrysophid species could be considered for a possible bio-control of aphids on the plants.

Coccinella septempunctata and $C$. bipunctata (Coccinellidae) are among the most common aphidophagous species in Turkey (Demirsoy 1990, Iperti 1999, Yurtsever 2001). Harmonia axyridis is a polyphagous coccinellid species that feeds mostly on aphids but it also preys on other pests (lepidopter eggs, coccoids, psyllids, tetranychids, and thrips) of agricultural and ornamental plants. From this point of view, the polyphagous habit of $H$. axyridis might contribute to the survival of rosaceous plants like Crataegus sp. and Prunus sp. in presence of pest insect species (Adriaens et al. 2008, Helyer et al. 2014). However, there are reported cases that $H$. axyridis might sometimes attack non-pest insect species (Helyer et al. 2014). C. bipunctata and $H$. axyridis are used as biological control agents against Aphididae throughout the world. Exochomus quadripustulatus, another coccinellid species we observed in the present study, is also an important predator feeding both on aphids and coccoids (FarooqAhmad 2012). Rosaceous plants reported to be associated with $C$. septempunctata are Amygdalus communis, Prunus armeniaca Linnaeus, $P$. avium Linnaeus, $P$. cerasifera Ehrh., Rubus caesius Linnaeus; with $C$. bipunctata are Malus communis Linnaeus, Persica vulgaris Mill., Prunus armeniaca, P. avium, Rosa sp.; and with E. quadripustulatus are Malus communis, Prunus amygdalus Batsch, P. avium, P. domestica, P. persica Linnaeus, and Pyrus communis (Soydanbay (Tunçyürek) 1978, Iperti 1999, Erler 2004, Aslan and Uygun 2005, Başar and Yaşar 2011). C. septempunctata and $H$. 
axyridis are known to feed sometimes with pollen (Lundgren 2009) but this habit of these two species was not observed in the present study. Intraspecies cannibalism was determined to occur among $C$. septempunctata and $H$. axyridis larvae reared in laboratory conditions (Iperti 1999). Cannibalism is common among larvae and adults during laboratory rearing (Iperti 1999) and is biologically advantageous for the cannibal coccinellid (Hawkes 1920). In this study, we observed that the last instars of $C$. septempunctata larvae preyed on their conspecifics despite the presence of aphids. C. septempunctata was reported to show cannibalism towards its eggs also in the presence of aphids (Khan et al. 2003). According to Toft and Wise (1999) and Khan et al. (2003), a mixed diet based on aphids and cannibalism on conspecifics has a positive contribution to their larval survival and their developmental period. On the other hand, when the available food (e.g. aphids) in their environment is limited, the individuals show usually cannibalistic behavior to survive. The food deficiency-caused cannibalism was observed in laboratory conditions among last instars of $H$. axyridis larvae. According to the studies on $H$. axyridis and $C$. bipunctata, cannibalism may have both positive and negative effects on the cannibal individual (Table 2).

Table 2. Positive and negative effects of cannibalism on the cannibal individual (Wagner et al. 1999, Dixon 2000, Snyder et al. 2000, Koch 2003, Ware et al. 2009).

\begin{tabular}{ll}
\hline \multicolumn{1}{c}{$\begin{array}{c}\text { Negative aspects of } \\
\text { cannibalism }\end{array}$} & \multicolumn{1}{c}{$\begin{array}{c}\text { Positive aspects of } \\
\text { cannibalism }\end{array}$} \\
\hline \hline $\begin{array}{l}\text { If prey-predator sizes are } \\
\text { nearly the same, the } \\
\text { cannibal can be in a prey } \\
\text { position during its predation } \\
\text { attempt or it can take } \\
\text { damage. }\end{array}$ & $\begin{array}{l}\text { Cannibalism provides the } \\
\text { dominant requirement of } \\
\text { immediately and decreases } \\
\text { competition for food. }\end{array}$ \\
$\begin{array}{l}\text { The dominant predator may } \\
\text { be negatively affected from } \\
\text { any parasite or viruse of its } \\
\text { prey. }\end{array}$ & $\begin{array}{l}\text { If cannibals feed on a } \\
\text { to parasites, cannibalism } \\
\text { gives an advantage for } \\
\text { possible diseases to it. }\end{array}$ \\
If the predator feeds on its \\
genetically close relatives \\
its inclusive fitness may be \\
lost.
\end{tabular} \begin{tabular}{l}
$\begin{array}{l}\text { A mixed diet, composed of } \\
\text { aphid and cannibalism, leads } \\
\text { development and and higher } \\
\text { survival of cannibals due to } \\
\text { high quality of its food. }\end{array}$ \\
\hline
\end{tabular}

Episyrphus balteatus and Eupeodes corollae are generalist predators with their larvae feeding mostly on aphids and adults on nectar and pollen (Cowgill et al. 1993, Lindsey 2015). Because of the effective predatory feature of their larvae, these species are important in biocontrol of aphids (Zeki and Kilınçer 1990, Cowgill et al. 1993, Putra and Yasuda 2006). Rosaceous plants on which E. balteatus larvae find their prey are Malus domestica and Prunus domestica (Pehlivan and Atakan 2014). Bolu and Hayat (2008) quoted Rosaceae plant associates of E. corollae as Amygdalus communis, Malus communis, M. floribunda Siebould ex Van Houtte, Prunus armeniaca, P. avium, P. domestica, P. mahaleb Linnaeus, P. persica, Pyrus communis, Rosa sp., and Rubus fruticosus Linnaeus. Plants have important indirect effects on predators like E. balteatus as they can affect the development of larvae and pupae of the predators through their aphid preys (Dyer 1995, Amiri-Jami et al. 2015). According to a study carried out by Vanhaelen et al. (2002), specialist aphids feed on their preferred plant if it is rich in its specific metabolites. In addition, when syrphids feed on these specialist aphids, their development, survival rate, fecundity, and reproduction may be negatively affected because high content of plant allelochemicals can be toxic and transferred to the predator through the aphid prey.

The geocorid bug, Geocoris erythrocephalus, feeds on small insects in several different habitats all with rosaceous plants. The associated plant species belonging to this family are Crateagus sp., Prunus armeniaca, Pyrus angustifolia Aiton, P. malus, Rosa sp., and Rubus sp. (Lodos et al. 1999, Torma 2009, Matocq et al. 2014). The members of Geocorinae subfamily are mostly predators feeding on soft-bodied insects. They generally prey upon mites and insects which are pests of many ornamental and crop plants (Çakır and Önder 1990, Ulubilir and Yabaş 1995, Öztemiz 2012, Mead 2001). In this study, G. erythrocephalus individuals were recorded from Prunus spinosa and visited the plant probably in search of prey items.

The two-spotted stink bug Perillus bioculatus nymphs show a high gregariousness during their first instars. Other stink bugs change their behavior from gregarious to solitary in late instars but $P$. bioculatus nymphs may still show gregarious behaviors to some extent until their last instars (Schaefer and Panizzi 2000). P. bioculatus were observed in their first or second instars and they showed a high gregarious behavior. These instars do not feed during these developmental stages and just provide their humidity needs from the plant sap. They start to feed on insect preys after the second instar. There are many reported cases that predatory insects like $P$. bioculatus can detect the plant originating volatiles as a result of herbivorous feeding (Dickens 1999, Weissbecker et al. 1999, Schaefer and Panizzi 2000).

Crematogaster ionia foragers were observed in a lepidopteran nest of rolled leaves. When they were first noticed, foragers had already fed on some part of the lepidopteran pupa. Considering the fact that the lepidopteran pupa remains were already dried up when the ants attacked, it is most likely to conclude that foragers were feeding on an already dead lepidopteran body. Although not certain, the remains of the partly consumed pupa looked like to be a pupa of a tortricid. Crematogaster foragers were reported to feed mainly on honeydew during their visits on plants, but eggs and larval and pupal stages of several aphid species are also preyed on. The predatory behavior of the genus has formerly been well 
documented (Du Merle and Mazet 1983, Richard et al. 2001). Radeghieri (2004) recorded C. scutellaris preying upon larvae and pupae of a lepidopteran species (Gracillariidae). C. ionia feeds on honeydew of members of Coccoidea (Coccidae and Marchalinidae) (Ülgentürk 2001, Ülgentürk et al. 2012). C. ionia has also a facultative mutualistic association with Lepidoptera (Lycaenidae) larvae in which foragers feed on larval secretions (Fiedler, 2010). However, the ant species for this record of Fiedler (2010)'s study is not precise, stated as "Crematogaster cf. ionia". Although Karaman (2010) reported that there is not much data about $C$. ionia ecology, workers of this species are generalized omnivores.

In conclusion, predatory insects associated with some Rosaceae species were investigated in this study. A total of 11 predatory insects belonging to 6 families were

\section{References}

1. Adriaens, T., San Martin, G. \& Maes, D. 2008. Invasion history, habitat preferences and phenology of the invasive ladybird Harmonia axyridis in Belgium. Pp. 69-88. In: Roy, H.E. \& Wajnberg E. (eds) Biological Control to Invasion: The Ladybird Harmonia axyridis as a Model Species. Springer Science \& Business Media, Netherlands, 290 pp.

2. Aldini, R.N. 2012. Lacewings (Neuroptera) as beneficial insects in orchards: findings for plum and cherry trees in Lombardy (northern Italy). Proceedings of the Joint Meeting of the sub-Groups Pome Fruit Arthropods and Stone Fruits: Workshop on Sustainable Protection of Fruit Crops in the Mediterranean Area, 12-17 September, Italy, 203-208

3. Amiri-Jami, A.R., Sadeghi-Namaghi, H., Gilbert, F., Moravvej, G. \& Asoodeh, A. 2015. On the role of sinigrin (mustard oil) in a tritrophic context: plant-aphidaphidophagous hoverfly. Ecological Entomology, 41(2): 138-146.

4. Aslan, M.M. \& Uygun, N. 2005. The aphidophagus coccinellid (Coleoptera: Coccinellidae) species in Kahramanmaraş, Turkey. Turkish Journal of Zoology, 29(1): $1-8$.

5. Barbosa, P. \& Letourneau, D.K. 1988. Novel Aspects of Insect-Plant Interactions. Wiley, New York, 362 pp.

6. Başar, M.K. \& Yaşar, B. 2011. Determination of Ladybird species (Coleoptera: Coccinellidae) on fruit trees in Isparta, Turkey. Turkish Journal of Entomology, 35(3): 519-534.

7. Bolu, H. \& Hayat, R. 2008. A new host [Parthenolecanium persicae (Homoptera: Coccidae)] record for Eupeodes corollae (Fabricius) (Diptera: Syrphidae) from Turkey. Turkish Journal of Zoology, 32(1): 79-84.

8. Boo, K.S., Chung, I.B., Han, K.S., Pickett, J.A. \& Wadhams, L.J. 1998. Response of the lacewing Chrysopa cognala to pheromones of its aphid prey. Journal of Chemical Ecology, 24(4): 631-643.

9. Bozsik, A. 1992. Natural adult food of some important Chrysopa species (Planipennia: Chrysopidae). Acta Phytopathologica et Entomologica Hungarica, 27(1-4): 141-146. determined on 5 Rosaceae species. Some relevant information about behavioral patterns of these insects was given under the tritrophic concept. To understand the complete mechanism underneath, it is important to study several topics, i.e. associations, interactions, allelochemicals, and genetic relationships, regarding the predators and the plants on which the predators find their preys.

\section{Acknowledgement}

The authors would like to thank to Meral Fent (Hemiptera), Nihat Aktaç (Formicidae), and Rüstem Hayat (Syrphidae) for identification of the species. The findings used in this article is a part of the master's thesis of the first author and has been presented as a poster on $23^{\text {rd }}$ National Biology Congress held in Gaziantep, Turkey on 5-9 September 2016.

10. Bozsik, A. 2006. Lacewings' occurrence in some Hungarian hedgerows and field edges. Proceedings of the $4^{\text {th }}$ International Plant Protection Symposium at Debrecen University, 18-19 October, Hungary, 141-150.

11. Cowgill, S.E., Wratten, S.D. \& Sotherton, N.W. 1993. The selective use of floral resources by the hoverfly Episyrphus balteatus (Diptera: Syrphidae) on farmland. Annals of Applied Biology, 122(2): 223-231.

12. Çakır, S. \& Önder, F. 1990. Some systematic and faunistic studies on Geocorinae (Het.: Lygaeidae) from Turkey. Turkish Journal of Entomology, 14 (1): 37-52.

13. Çam, H. 1993. Some studies on the heteropterous species collected on mahalep, sweet and sour cherries trees in Tokat and surrounding area, Gaziosmanpaşa University Journal of Agricultural Faculty. 10(1): 32-42.

14. Çınar, M., Çimen, İ. \& Bolu, H. 2004. The cherry pests, their natural enemies and observations on some important species in Elazığ and Mardin provinces of Turkey. Turkish Journal of Entomology, 28(3): 213-220.

15. Demirözer, O. \& Karaca, İ. 2014. Predator and parasitoid species associated with oil-bearing rose (Rosa damascena Miller) production areas in Isparta province with distributional remarks. Turkish Bulletin of Entomology, 4(3): 171-184.

16. Demirsoy, A. 1990. Yaşamın Temel Kuralları. II. Omurgasızlar/Böcekler. Volume II, Meteksan Publishing, Ankara, 941 pp.

17. Dickens, J.C. 1999. Predator-prey interactions: olfactory adaptations of generalist and specialist predators. Agricultural and Forest Entomology, 1(1): 47-54.

18. Dixon, A.F.G. 2000. Insect Predator-Prey Dynamics: Ladybird Beetles and Biological Control. Cambridge University Press, Cambridge, 257 pp.

19. Du Merle, P. \& Mazet, R. 1983. Mortality factors of the eggs of Tortrix viridana L. (Lep., Tortricidae). I. The predator complex (Hym., Formicidae; Derm., Forficulidae; Orth., Phaneropteridae; Neur., Chrysopidae). Agronomie, 3(3): 239-246. 
20. Dyer, L.A. 1995. Tasty generalists and nasty specialists? Antipredator mechanisms in tropical lepidopteran larvae. Ecology, 76(5): 1483-1496.

21. Erler, F. 2004. Natural enemies of the pear psylla Cacopsylla pyri in treated vs untreated pear orchards in Antalya, Turkey. Phytoparasitica, 32(3): 295-304.

22. Farooq-Ahmad, K. 2012. Development and growth of Exochomus quadripustulatus (Coleoptera: Coccinellidae): a predator of mussel scale Lepidosaphes ulmi (Homoptera: Diaspididae) on apple. Pakistan Journal of Zoology, 44(4): 1021-1028.

23. Fiedler, K. 2006. Ant-associates of Palaearctic lycaenid butterfly larvae (Hymenoptera: Formicidae; Lepidoptera: Lycaenidae) - a review. Myrmecologische Nachrichten, 9: 77-87.

24. Flora of China, 2004. Vol. 9, p. 46. Online Floras Database. http://www.efloras.org/florataxon.aspx?flora_id=2\&taxon _id=10776 (Data accessed: September 2016).

25. Google Earth, 2015. http://www.earth.google.com (Data accessed: March 2015).

26. Hawkes, O.A.M. 1920. Observations on the life-history, biology and genetics of the lady-bird beetle, Adalia bipunctata (Mulsant). Proceedings of the Zoological Society of London, 78: 475-490.

27. Helyer, N., Cattlin, N.D. \& Brown, K.C. 2014. Biological control in plant protection: a colour handbook. $2^{\text {nd }}$ edition, CRC Press, Boca Raton, 276 pp.

28. Hummer, K.E. \& Janick, J. 2009. Rosaceae: taxonomy, economic importance, genomics. Pp. 1-17. In: Folta, K.M. \& Gardiner, S.E. (eds) Genetics and Genomics of Rosaceae. Springer, New York, 636 pp.

29. Hyeon, S.B., Isoe, S. \& Sakan, T. 1968. The structure of neomatatabiol, the potent attractant for Chrysopa from Actinidia polygama. Tetrahedron Letters, 51: 5325-5326.

30. Iperti, G. 1999. Biodiversity of predaceous Coccinellidae in relation to bioindication and economic importance. Agriculture Ecosystems \& Environment, 74(1-3): 323-342.

31. Karaman, M.G. 2010. New data of the genus Crematogaster Lund, 1831 (Hymenoptera: Formicidae) in Crna Gora (Montenegro), Part I: Crematogaster scutellaris group of species. Turkish Journal of Entomology, 34(4): 419-434.

32. Khan, M.R., Khan, M.R. \& Hussein, M.Y. 2003. Cannibalism and interspecific predation in ladybird beetle Coccinella septempunctata (L.) (Coleoptera: Coccinellidae) in laboratory. Pakistan Journal of Biological Sciences, 6(24): 2013-2016.

33. Kılıç, M. \& Aykaç, M.K. 1989. Investigations on the pest management in peach orchards in the black sea region of Turkey. Plant Protection Bulletin, 29(3-4): 211-241.

34. Kılınçer, N. 1983. Ankara'da gül gal arıları (Rhodites spp.)'nın (Hym.: Cynipidae) üzerinde araştırmalar. Plant Protection Bulletin, 23(1): 1-11.

35. Koch, R.L. 2003. The multicolored Asian lady beetle, Harmonia axyridis: a review of its biology, uses in biological control, and non-target impacts. Journal of Insect Science, 3(32): 1-16.
36. Lindsey, J. 2005. Ecology of Commanster. Ecological Relationships Among More Than 6400 Species. http://www.commanster.eu/commanster/Insects/Flies/SpFl ies/Eupeodes.corollae.html (Data accessed: September 2016).

37. Lodos, N., Önder, F., Pehlivan, E., Atalay, R., Erkin, E., Karsavuran, Y., Tezcan, S. \& Aksoy, S. 1999. Faunistic studies on Lygaeidae (Heteroptera) of Western Black Sea, Central Anatolia and Mediterranean Regions of Turkey. Ege University, İzmir, $58 \mathrm{pp}$.

38. Lundgren, J.G. 2009. The Pollen Feeders. Relationships of Natural Enemies and Non-Prey Foods. Pp. 87-116. In: Lundgren J.G. (ed) Relationships of natural enemies and non-prey foods. Springer, The Netherlands, $453 \mathrm{pp}$.

39. Matocq, A., Pluot-Sigwalt, D. \& Özgen, İ. 2014. Terrestrial Hemiptera (Heteroptera) collected in South-East Anatolia (Diyarbakır, Mardin and Elazı̆ Provinces) (Turkey): second list. Munis Entomology \& Zoology, 9(2): 884-930.

40. McEwen, P., New, T.R. \& Whittington, A.E. 2001. Lacewings in the Crop Environment. Cambridge University Press, Cambridge, 546 pp.

41. Mead, F.W. 2001. Big-eyed bugs (of Florida) - Geocoris spp. (Insecta: Hemiptera: Lygaeidae), University of Florida.

http://entomology.ifas.ufl.edu/creatures/beneficial/bigeyed _bugs.htm (Data accessed: September 2016).

42. Öztemiz, S. 2012. Misırda Biyolojik Mücadele. Pp. $155-$ 188. In: Birişik, N. (ed). Teoriden Pratiğe Biyolojik Mücadele. Ministry of Food Agriculture and Livestock, General Directorate of Food and Control, Ankara, Turkey, $226 \mathrm{pp}$.

43. Pappas, M.L., Broufas, G.D. \& Koveos, D.S. 2011 Chrysopid predators and their role in biological control. Journal of Entomology, 8(3): 301-326.

44. Paulian, M., Canard, M., Thierry, D. \& Ciubuc, C. 2001. Survey of green lacewings in southern Transylvania, Romania, with some ecological notes (Neuroptera: Chrysopidae). Journal of Neuropterology, 3: 25-31.

45. Pehlivan, S. \& Atakan, E. 2014. Syrphidae (Diptera) species of the Balcalı location in Adana province, Turkey. Turkish Journal of Biological Control, 5(1): 53-66.

46. Putra, N.S. \& Yasuda, H. 2006. Effects of prey species and its density on larval performance of two species of hoverfly larvae, Episyrphus balteatus de Geer and Eupeodes corollae Fabricius (Diptera: Syrphidae). Applied Entomology and Zoology, 41(3): 389-397.

47. Radeghieri, P. 2004. Cameraria ohridella (Lepidoptera Gracillariidae) predation by Crematogaster scutellaris (Hymenoptera Formicidae) in Northern Italy (Preliminary note). Bulletin of Insectology, 57(1): 63-64.

48. Richard, F.J., Fabre, A \& Dejean, A. 2001. Predatory behaviour in dominant arboreal ant species: the case of Crematogaster sp. (Hymenoptera Formicidae). Journal of Insect Behavior, 14(2): 271-282.

49. Schaefer, C.W. \& Panizzi, A.R. 2000. Heteroptera of Economic Importance. CRC Press, Boca Raton, FL, 856 pp. 
50. Schmitz, O., Hamback, P. \& Beckerman, A. 2000. Trophic cascades in terrestrial systems: a review of the effects of carnivore removals on plants. The American Naturalist, 155(2): 141-153.

51. Schoonhoven, L.M., Van Loon, J.J. \& Dicke, M. 2005. Insect-Plant Biology. $2^{\text {nd }}$ edition, Oxford University Press, Oxford, $440 \mathrm{pp}$.

52. Snyder, W.E., Joseph, S.B., Preziosi, R.F., Moore, A.J. 2000. Nutritional benefits of cannibalism for the lady beetle Harmonia axyridis (Coleoptera: Coccinellidae) when prey quality is poor. Environmental Entomology, 29(6): 11731179.

53. Soydanbay (Tunçyürek), M. 1978. The list of natural enemies agricultural crop pests in Turkey. Part II. Plant Protection Bulletin, 16 (1): 32-45.

54. Toft, S. \& Wise, D.H. 1999. Growth, development, and survival of a generalist predator fed single-and mixedspecies diets of different quality. Oecologia, 119(2): 191197.

55. Torma, A. 2009. Data to the terrestrial Heteroptera fauna of Moldova. Acta Scientiarum Transylvanica, 17(1): 105-118.

56. Ulubilir, A. \& Yabaş, C. 1995. Population fluctuations, natural enemies and chemical control possibilities of cotton white fly (Bemisia tabaci Genn.) on vegetables in Çukurova. Plant Protection Bulletin, 35(3-4): 191-210.

57. Ülgentürk, S. 2001. Ants (Hymenoptera: Formicidae) associated with soft scale insects in Turkey: a preliminary list. Acta Phytopathologica et Entomologica Hungarica, 36(3-4): 405-409.

58. Ülgentürk, S., Kıran, K., Ayhan, B., Civelek, H.S. \& Eskin, A. 2012. Ant species (Hymenoptera: Formicidae) associated with Marchalina hellenica Gennadius (Hemiptera: Marchalinidae) in Turkey. Turkish Bulletin of Entomology, 2(4): 263-270.

59. van Emden, H.F. \& Harrington, R. 2007. Aphids as Crop Pests. CABI, Cambridge, 800 pp.

60. Vanhaelen, N., Gaspar, C. \& Francis, F. 2002. Influence of prey host plant on a generalist aphidophagous predator: Episyrphus balteatus (Diptera: Syrphidae). European Journal of Entomology, 99(4): 561-564.

61. Wagner, J.D., Glover, M.D., Mosely, J.B. \& Moore, A.J. 1999. Heritability and fitness consequences of cannibalism in Harmonia axyridis. Evolutionary Ecology Research, 1: 375-388.

62. Ware, R.L., Yguel, B. \& Majerus, M.E.N. 2009. Effects of competition, cannibalism and intra-guild predation on larval development of the European coccinellid Adalia bipunctata and the invasive species Harmonia axyridis. Ecological Entomology, 34(1): 12-19.

63. Weissbecker, B., Van Loon, J.J.A \& Dicke, M. 1999. Electroantennogram responses of a predator, Perillus bioculatus, and its prey, Leptinotarsa decemlineata, to plant volatiles. Journal of Chemical Ecology, 25(10): 23132325.

64. Yurtsever, S. 2001. A preliminary study on the ladybirds (Coleoptera: Coccinellidae) of Edirne in north-western Turkey. Turkish Journal of Zoology, 25: 71-75.

65. Zeki, C. \& Kılınçer, N. 1990. Investigations on the development of Episyrphus balteatus (De Geer) (Diptera, Syrphidae) on different aphid species. Proceeding of the Second Turkish National Congress of Biological Control, 26-29 September, Ankara-Turkey, 137-145. 
